\title{
Light and Transmission Electron Microscopic Study of Olfactory Organ of Spotted Snakehead, Channa punctata (Bloch)
}

\author{
Prakash Ghodeswar ${ }^{1}$, Nilesh Gorghate ${ }^{2}$, Suresh Masram ${ }^{1, *}$ \\ ${ }^{1}$ Department of Zoology, RTM Nagpur University, Nagpur (M.S.), India \\ ${ }^{2}$ Department of Zoology, M.B. Patel College, Sadak Arjuni, Dist- Gondia (M.S.), India
}

Received July 27, 2020; Revised August 25, 2020; Accepted September 29, 2020

\section{Cite This Paper in the following Citation Styles}

(a): [1] Prakash Ghodeswar, Nilesh Gorghate, Suresh Masram, "Light and Transmission Electron Microscopic Study of Olfactory Organ of Spotted Snakehead, Channa punctata (Bloch)," Advances in Zoology and Botany, Vol. 8, No. 6, pp. 483 - 490, 2020. DOI: 10.13189/azb.2020.080602.

(b): Prakash Ghodeswar, Nilesh Gorghate, Suresh Masram (2020). Light and Transmission Electron Microscopic Study of Olfactory Organ of Spotted Snakehead, Channa punctata (Bloch). Advances in Zoology and Botany, 8(6), 483 - 490. DOI: 10.13189/azb.2020.080602.

Copyright $(2020$ by authors, all rights reserved. Authors agree that this article remains permanently open access under the terms of the Creative Commons Attribution License 4.0 International License

\begin{abstract}
The olfactory organ of Channa punctata (Bloch) has been studied under light microscope and transmission electron microscope. The olfactory apparatus of C. punctata comprises of olfactory rosette, olfactory nerve, and olfactory bulb. Paired, oval shaped olfactory rosette present in the olfactory chamber on fish rostrum. Olfactory chamber opens externally via an anterior inlet and a posterior nostril outlet. Olfactory epithelium comprises of sensory and non-sensory regions. Sensory region is at basal part and non-sensory region is at proximal area of olfactory lamellae. In olfactory lamellae, sensory epithelium consists of olfactory receptor cells, supporting cells, basal cells, goblet cells, mucous cell and white cell. Olfactory receptor cells are of two types microvillous and ciliated. In C. punctata, olfactory bulb is sessile and is attached to the telencephalon. Cells of olfactory bulb are organized in four concentric layers. Outer layer is olfactory nerve layer formed by axons of olfactory receptor cells. Inner to it is glomerular layer where axons of olfactory receptor cells synapse with dendrites of mitral cells. Next towards deeper part is mitral cell layer which comprises larger multipolar mitral cells. Central core is formed by granular cell layer with small granular cells.
\end{abstract}

Keywords Channa punctata, Olfactory Rosette, Olfactory Bulb, Olfactory Epithelium

\section{Introduction}

The olfactory system brings about responses to a mass of different stimuli vital for the interaction of an organism with its surrounding environment as well as with congener. The stimuli are identified by receptor cells with odorant receptors and the information is transmitted to the olfactory bulb [1]. Number of investigators has been earlier described the structure of the olfactory organ in the teleostean fishes. The teleostean olfactory organ exhibits various variations due to differences in habit and habitat. The structure of the olfactory epithelium in fishes have been investigated by several researchers revealing remarkable diversity exist regarding the shape, number, and arrangement of the olfactory lamellae, the distribution of sensory and non-sensory epithelium as well as variations in olfactory receptor cells in different teleosts [2-7]. Surface ultrastructure of olfactory epithelium although studied in C. punctata [4], cellular ultrastructure of olfactory epithelium and olfactory bulb is not yet explored. The present study is an attempt to examine the histology with the help of light microscope (LM) and transmission electron microscopic (TEM) structure of the olfactory epithelium and olfactory bulb of spotted snake head $C$. punctata. 


\section{Materials and Methods}

\section{Collection of Fishes}

Adult C. punctata fish of both sexes weighing about 200 gm- $250 \mathrm{gm}$ are collected from the natural water bodies in and around Nagpur city. They were brought to the laboratory and acclimatized in the well aerated glass aquaria for 15 days. Fishes were cared and treated in accordance with protocol of Institutional Animal Ethics Committee (IAEC), Post Graduate Teaching Department of Zoology, Rashtrasant Tukadoji Maharaj Nagpur University, Nagpur (Registration no. 478/01/a/CPC SEA).

\section{Light Microscopy}

For Histological studies, the fishes were anesthetized with 2-phenoxyethanol and sacrificed. Olfactory organs were dissected out and fixed in aqueous Bouin's fixative for $24 \mathrm{hrs}$. Tissues fixed in the Bouin's fixative were transferred to $70 \%$ ethanol and dehydrated in ascending graded series of ethanol, cleared in xylene and embedded in paraffin wax. Sections of olfactory rosette and olfactory bulb were cut on rotary microtome (model- RMT-30) at $8 \mu \mathrm{m}$ thickness in transverse as well as in lateral planes and stained with hematoxylene and eosine (double staining), and Niss'l staining technique [8].

\section{Transmission Electron Microscopy}

The fish were anesthetized with 2-phenoxy ethanol. The olfactory rosette was perfused with $0.1 \mathrm{M}$ phosphate buffer (PB) ( $\mathrm{pH}$ 7.4). The rosettes were then carefully dissected out and primarily fixed in cold $2.5 \%$ glutaraldehyde containing $2 \%$ paraformaldehyde in $0.1 \mathrm{M} \mathrm{PB}(\mathrm{pH} 7.4$ ). The tissues were washed in $\mathrm{PB}$ and post fixed in $1 \%$ osmium tetraoxide for $2 \mathrm{hrs}$ at $4^{0} \mathrm{C}$. After post fixation, the tissues were washed in $\mathrm{PB}$, dehydrated through ascending grades of ethanol, cleared in toluene and embedded in epoxy resin. Semi-thin sections of $1 \mu \mathrm{m}$ were stained with toluidine blue and examined by light microscope. Ultrathin sections were stained with uranyl acetate and lead citrate and observed under transmission electron microscope (TEM-Morgani) at Sophisticated Advanced Instrument Facility (SAIF), All India Institutes of Medical Sciences, New Delhi (India).

\section{Result}

Olfactory system of $C$. punctata comprises of paired olfactory rosette, olfactory nerve, and olfactory bulb (Fig. $1 \mathrm{a}$ and $1 \mathrm{~b}$ ). In C. punctata, olfactory rosette are paired and are situated dorso-laterally on the snout anterior to the eyes. Each organ present in the olfactory chambers that has two separate apertures through which water enters and leaves. Olfactory rosettes of C. punctata have numerous lamellae in parallel arrangement running in rostro-caudal direction (Fig.2a). These lamellae's acquire fibers from their proximal end and extend into olfactory nerve (Fig. 2a). Olfactory nerve is long and caudally connected to the olfactory bulb (Fig.2a). Olfactory nerve runs posterior and peripherally penetrates the olfactory bulb (Fig. 1a). In $C$. punctata, sensory region is at basal and middle part and non sensory region is at proximal area of olfactory lamellae (Fig.2a and 2b). Sensory epithelium consists of olfactory receptor cell (ORCs). Ciliated olfactory receptor cells (cORCs) which are columnar and bipolar cells bearing a cell body. A long dendrite with 7-8 long cilia arises towards outer side. cORCs bears elongated nucleus with denser nucleoplasm and nucleoli. Long axonal process arises from cyton and runs toward the basal lamina (Fig. 3). Microvillous olfactory receptor cells (mORCs) are also columnar but without cilia. mORCs have round nucleus and have olfactory knob (Fig. 5). Basal cells are small, oval in shape with a prominent nucleus lying in deeper part of the epithelium just above the basal lamina (Fig. 4 and 6). In basal cell, nucleus is quite large and occupies maximum area leaving very little space for cytoplasm. Mucous cells are large, oval glandular cells, found along with sensory and non-sensory epithelium (Fig. 5). Supporting cells are elliptical to columnar in shape without dendrite and axonal process (Fig. 4). Supporting cell show rounded nucleus and dense nuceloplasm (Fig 4.). Associated with nucleus, endoplasmic reticulum is observed (Fig.6)

In C. punctata, goblet cells are clearly identified (Fig.3). These cells are filled with Golgi complex and rough endoplasmic reticulum. White cell is seen in the olfactory epithelium of C. punctata (Fig.5). The sessile olfactory bulb shows four concentric layers. Olfactory Nerve Layer (ONL) is formed of axons of ORCs of C. punctata. Underneath ONL, glomerular layer (GL) manifest synapses of axons of ORCs with dendrites of mitral cells (MC) (Fig.9). MC are large sized cells with darkly stained nucleus which in turn form mitral cell layer (MCL) towards inner side (Fig.10). MC are multipolar cells and clearly show numerous dendrites arising from its cyton towards GL. Nucleus of mitral cell is triangular with dense nucleoplasm and nucleoli (Fig.10). In MCL, along with mitral cells smaller glial cells too are observed (Fig.11). In the centre, densely packed smaller granular cells (GC), are present which form granular cell layer (GCL) (Fig.7). GC are bipolar cells and its nucleus occupies maximum part of cell body (Fig.10 and 11). GCL along with granular cell show glial cells (Fig.11).

In the olfactory bulb of $C$. punctata, on ventro-medial and dorso-medial side, giant cells of the NT have been identified (Fig.8). NT cells exhibit intense Niss'l staining (Fig.8). 


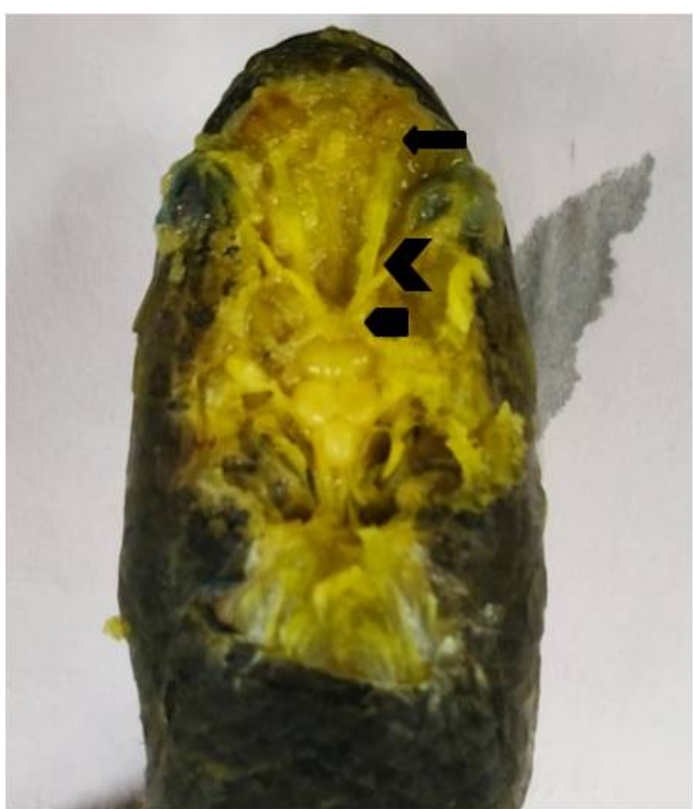

1a

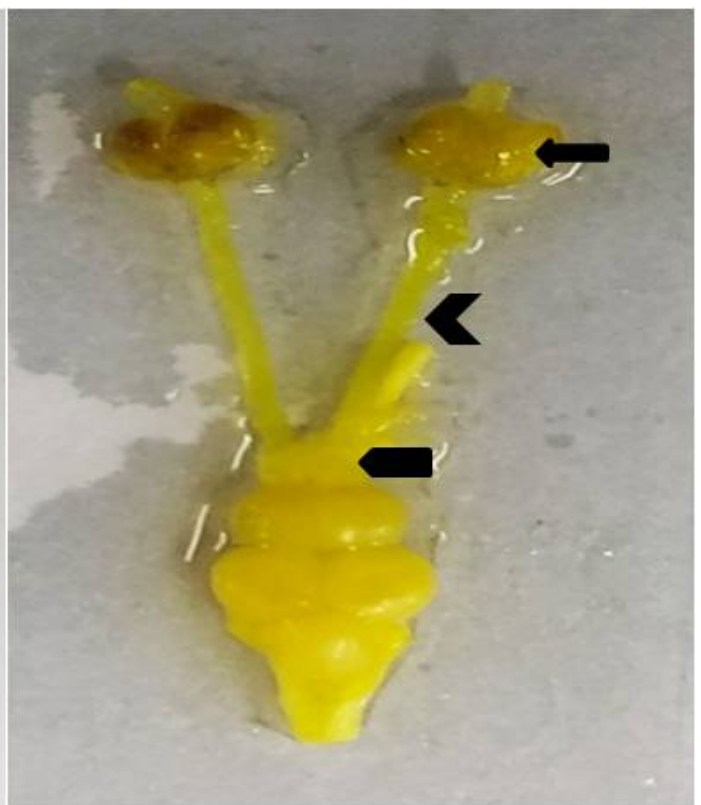

$1 \mathrm{~b}$

Figure 1. (a and b) Dissecting head of Channa punctata showing olfactory rosette OR (Arrow), olfactory nerve ON (Arrow head), and sessile olfactory bulb OB (Pentagon)

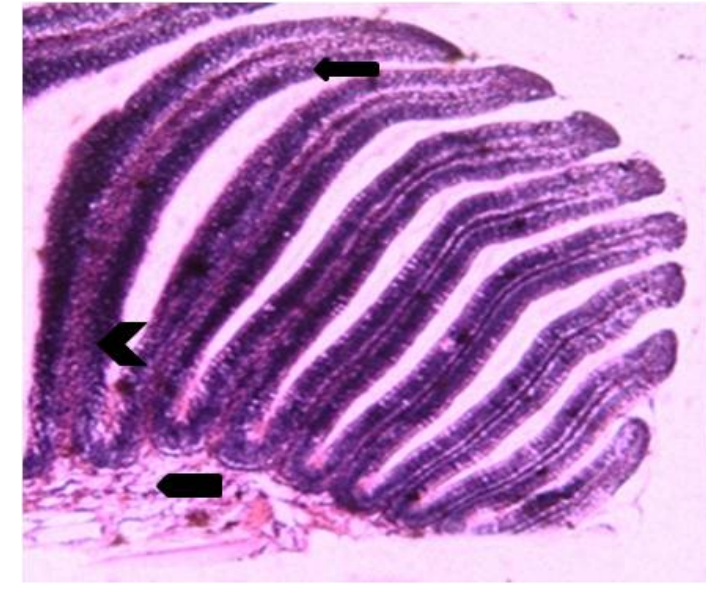

2a

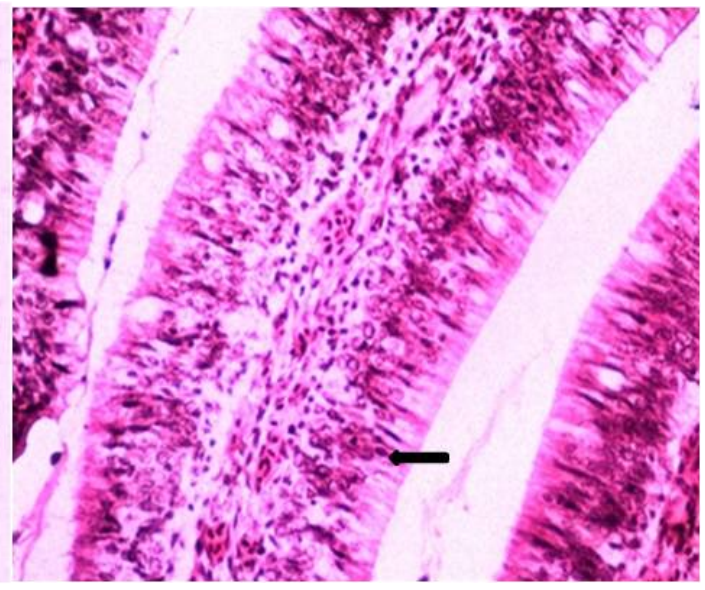

2b

Figure 2. a) TS of Olfactory lamellae of $C$. punctata showing sensory epithelium (Arrowhead), non sensory epithelium (Arrow), and fibers (pentagon) : HE $100 \mathrm{X}$ b) TS of sensory olfactory epithelium of C. punctata showing olfactory receptor neurons (arrow) HE $400 \mathrm{X}$ 


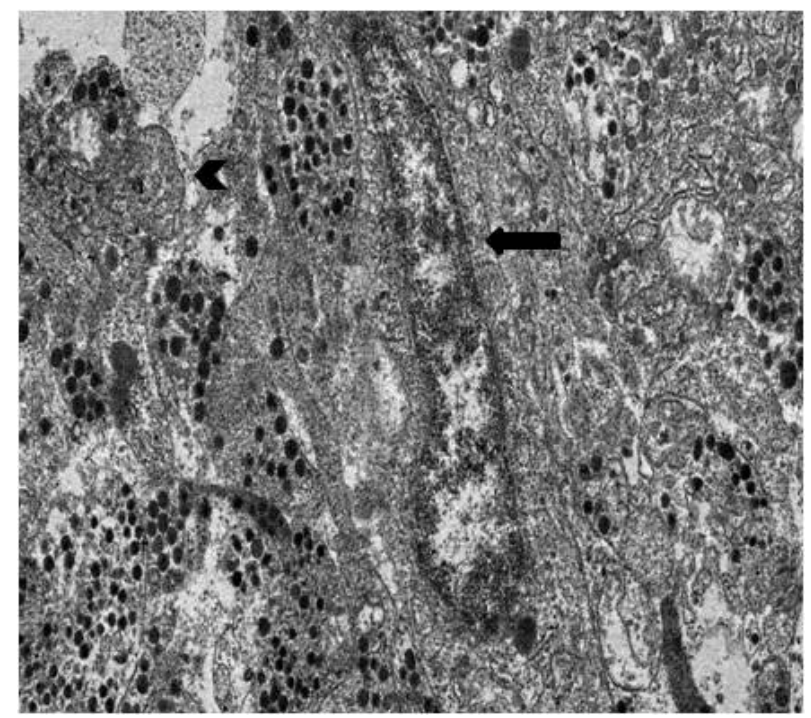

Figure 3. TEM photograph of sensory epithelium showing ciliated olfactory receptor cell cORC (arrow), and goblet cell (arrowhead) 18.1 $\mathrm{KX}$

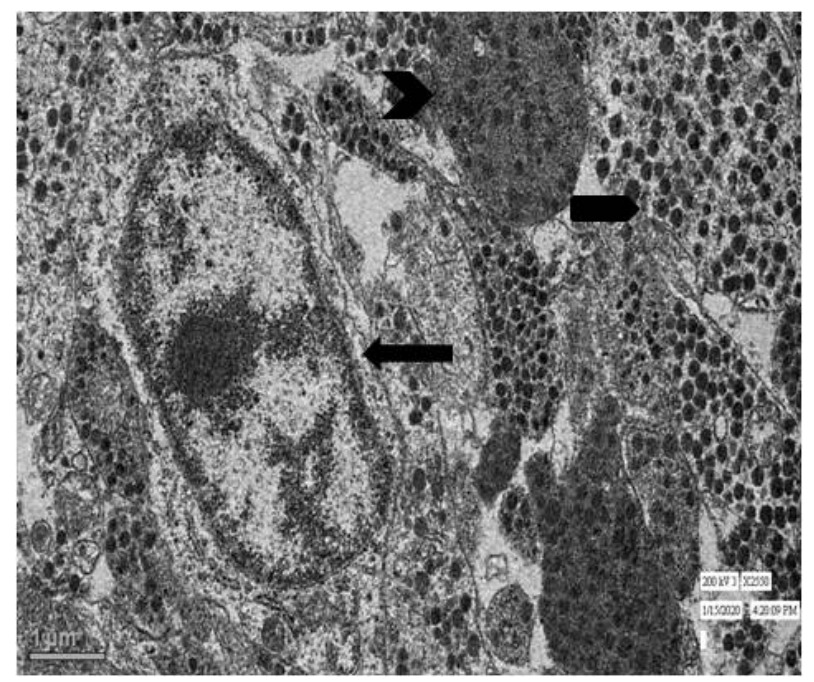

Figure 4. TEM photograph of sensory epithelium showing basal cell $\mathrm{BC}$ (arrow), supporting cell SC (arrow head), and mucous secreting cells (pentagon) $14.5 \mathrm{KX}$

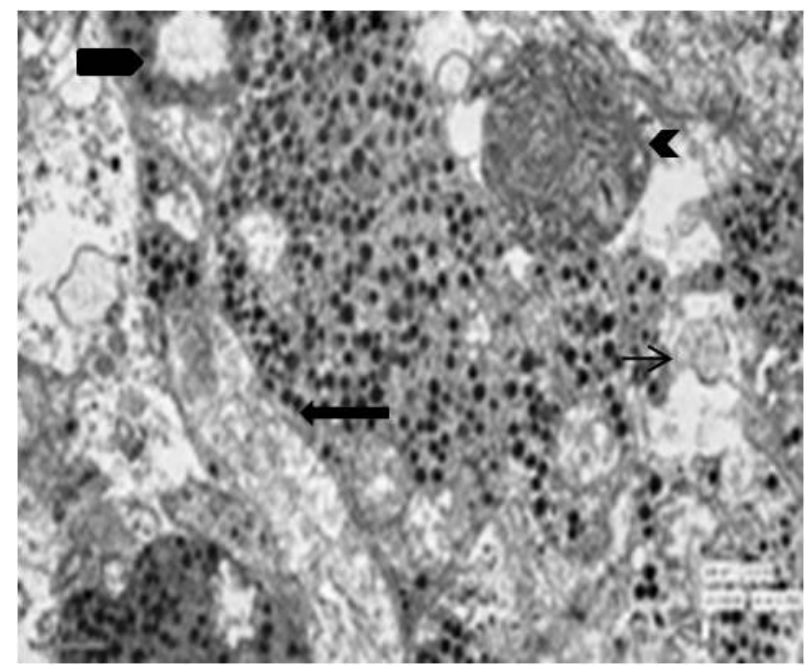

Figure 5. TEM photograph of sensory epithelium showing Microvillous olfactory receptor cells mORC (arrow), Golgi apparatus (arrow head), White cell (pentagon), and cistern (thin arrow) $14.5 \mathrm{KX}$

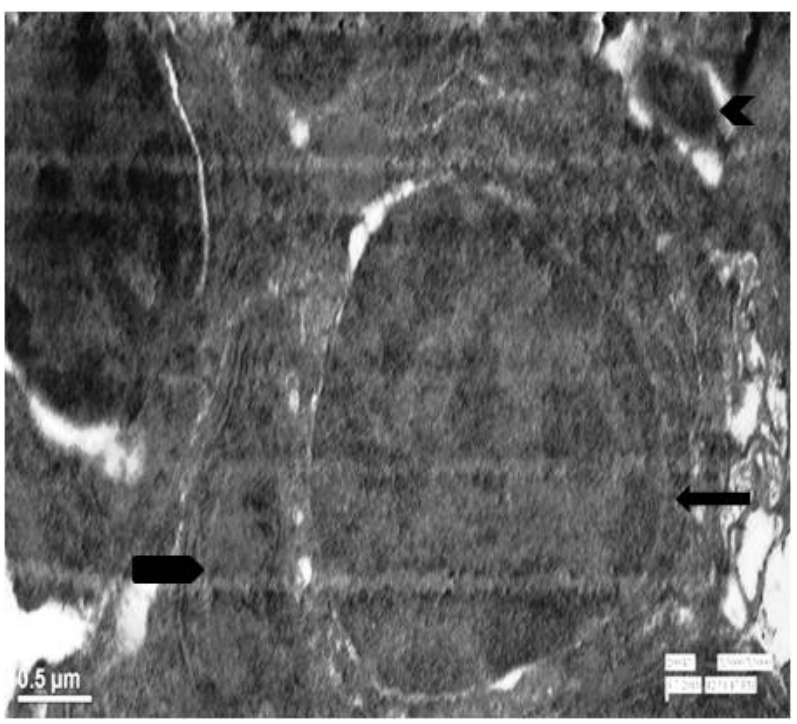

Figure 6. TEM photograph of sensory epithelium showing large nucleus of basal cell (arrow), chromatin lump (arrow head), and rough endoplasmic reticulum RER (pentagon) $4.5 \mathrm{KX}$ 


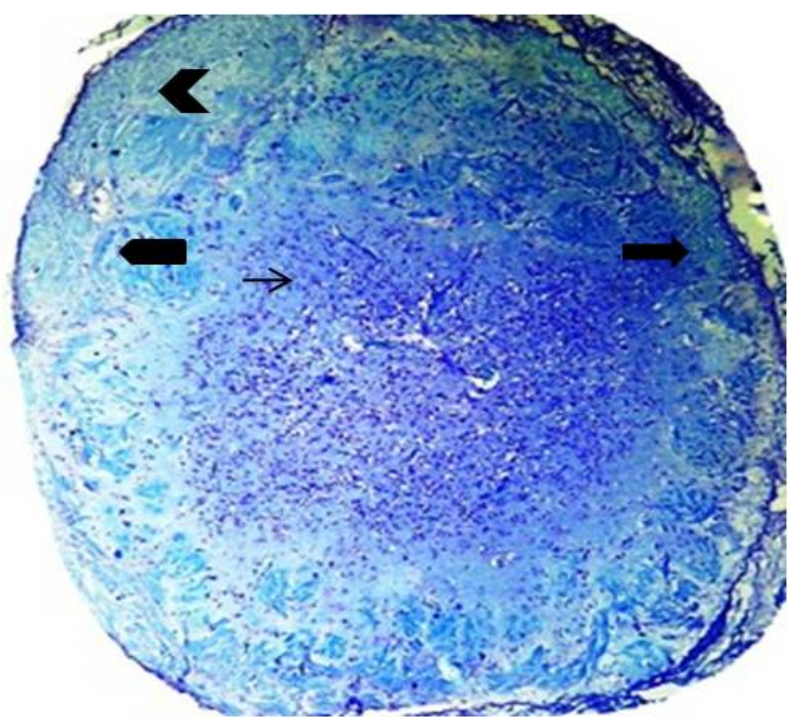

Figure 7. Transverse section of the olfactory bulb of C. punctata showing olfactory nerve layer ONL (arrow), Glomerular layer GL (arrow head), granular cell layer GCL (pentagon), and mitral cell layer MCL (thin arrow), Kluver and Barrera, 100X

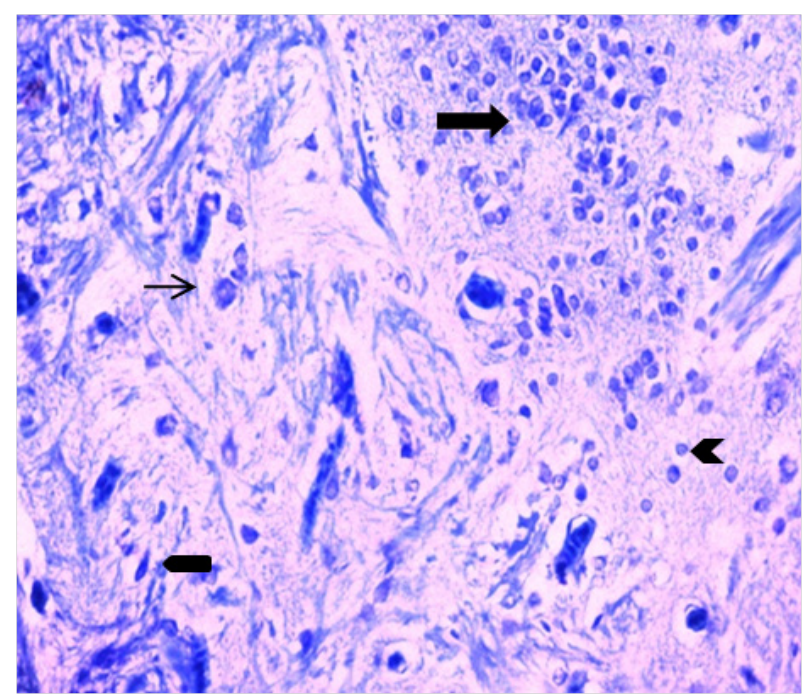

Figure 8. Transverse section of the olfactory bulb of C. punctata showing mitral cells MC (arrow), granular cells GC (arrow head), Glial cells (pentagon), and bigger sized neurons of nervous terminalis NT (thin arrow), Kluver and Barrera, 400X

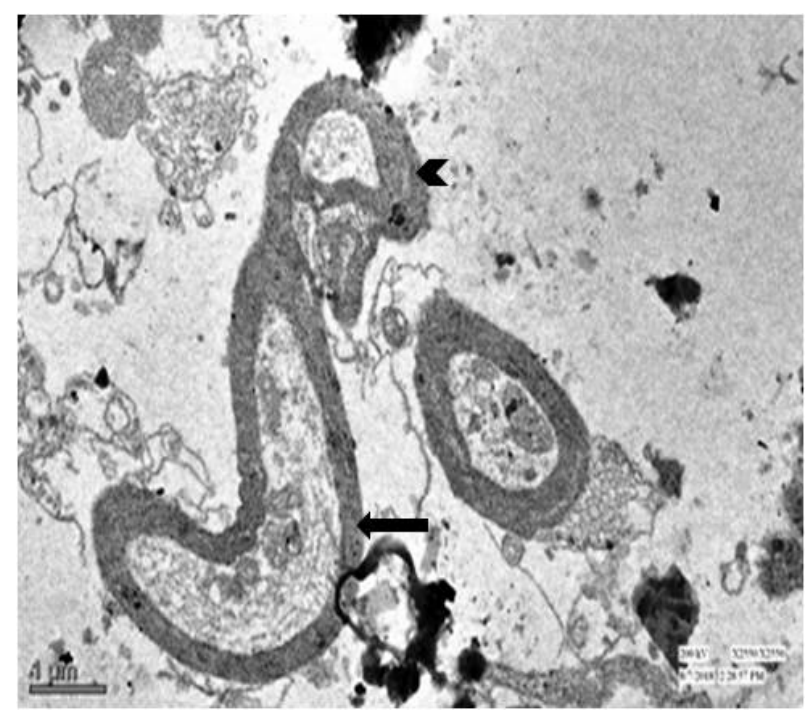

Figure 9. TEM photograph of olfactory bulb showing glomerular layer where axons of outer nerve layer ONL (arrow), synapse with dendrites of mitral cell (arrow head). $10 \mathrm{KX}$

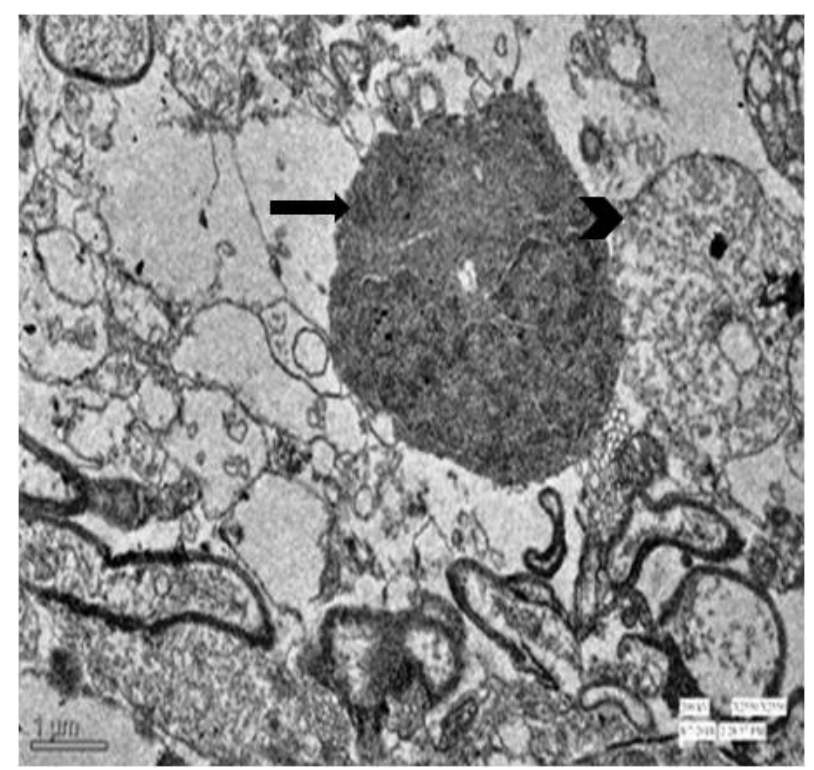

Figure 10. TEM photograph of olfactory bulb showing Mitral cell MC (arrow) and Glomerular cell GC (arrow head). $30 \mathrm{KX}$ 


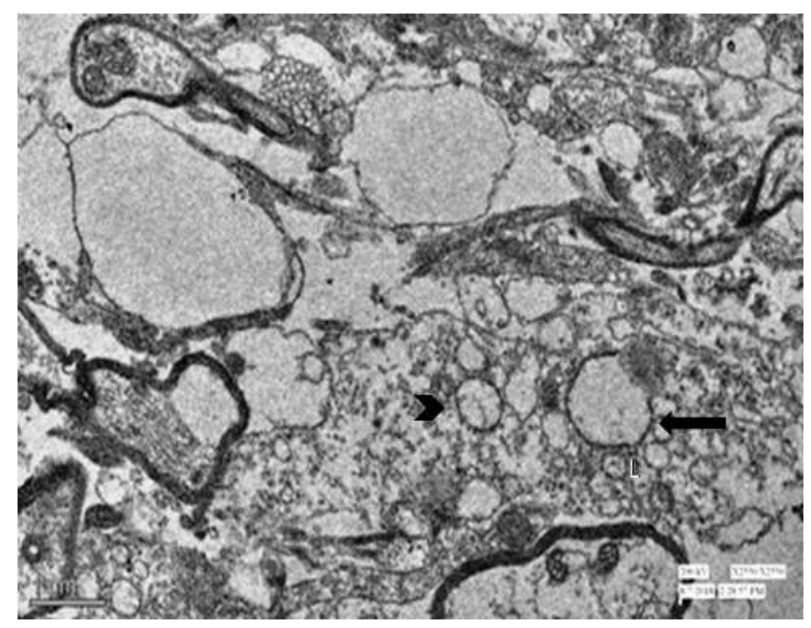

Figure11. TEM photograph of olfactory bulb showing granular cell (arrow) and Glial cell (arrow head). 15.5KX

\section{Discussion}

The olfactory apparatus is one of the important chemosensory organs of fish [9]. This organ analyzes the chemical nature of the surroundings environment by reception of different chemical cues. In C. punctata, olfactory rosette is oval in shape peculiarly do not show central raphe in olfactory rosette. Similar structure is also observed in Channa striata [10] and Channa gachua [11]. In C. punctata, olfactory rosette is paired and situated dorso-laterally on the snout anterior to the eyes. Each organ present in the olfactory chambers that has two separate apertures through which water enters and leaves. Olfactory rosettes of $C$. punctata have numerous lamellae in parallel arrangement running in rostro-caudal direction. In Labeo rohita [5], N. notopterus [11] and in other teleosts [12] olfactory lamellae are radiating outward from central raphe. These lamellae acquire fibers from their proximal end and extend into olfactory nerve. In C. punctata, olfactory epithelium is folded. Each lamella is crescentic in shape and bears linguiform process along its concave margin as in Catla catla [13] and in Puntius sarana [14]. Folding on the olfactory epithelium of lamellae increases the surface area of epithelium as well as sensitivity and efficiency of olfactory system $[2,11,14,15]$. These perspectives are supported by our study as olfactory rosette in C. punctata is multi lamellar rosette which may provide more surface area for binding of odorants and sensory activity.

In C. punctata, sensory region is at basal and middle part and non sensory region is at proximal area of olfactory lamellae as in C. striata [10] and C. gachua [11]. However, in the cyprinid L. rohita, sensory region at the middle of lamella and non sensory region is at the proximal and basal region of lamella [16]. In Rhodeus amarus, sensory region is at the base and middle of lamella and non sensory region at the proximal end [17]. In Heteropneustes fossilis, sensory region occupies middle of the lamellae [18].
In C. punctata, sensory epithelium consists of olfactory receptor cell (ORCs). Ciliated olfactory receptor cells (cORCs) which are columnar and bipolar cells bearing a cell body. cORCs bears elongated nucleus with denser nucleoplasm and nucleoli. Long axonal process arises from cyton and runs toward the basal lamina. Microvillous olfactory receptor cells (mORCs) are also columnar but without cilia. mORCs have round shape nucleus and have olfactory knob. cORCs and mORCs in sensory epithelium of olfactory rosette demonstrated in several teleosts $[10,16,1920,21]$. Between the basal and supporting cells, white cells and goblet cells are seen in the middle of olfactory epithelium in C. punctata, similar findings are observed in H. fossilis [22] and C. striata [10]. cORCs ontogenetically preceeds the mORCs [23], but according to some, cORCs and mORCs develop from identical stem cells $[24,25]$. Dense gathering of Golgi complex in receptor cells in $C$. punctata indicates secretary nature of receptor neurons. Presence of stimulatory neuropeptide, GnRH in the olfactory receptor cells and their projections to the olfactory bulb is revealed in Cirrhinus mrigala [26] suggesting the role of olfactory receptor cells in transduction of environmental cues and further transmitting it through brain-pituitary-gonadal axis. In the present study, ORCs are also characterized in C. punctata which may have a role in signal transduction in further areas of brain. Similar findings are explained by $[10,21,27]$.

Basal cells are small, oval in shape with a prominent nucleus lying in deeper part of the epithelium just above the basal lamina. In basal cell, nucleus is quite large and occupies maximum area leaving very little space for cytoplasm. Mucous cells are large, oval glandular cells, found along with sensory and non-sensory epithelium. Supporting cells are elliptical to columnar in shape without dendrite and axonal process. Supporting cell show rounded nucleus and dense nuceloplasm. Associated with nucleus, endoplasmic reticulum is observed. Besides ER, Golgi complex with its parallel arranged cisternae is observed. Presence of large number of vesicles and Golgi complex suggest the secretary nature of $\mathrm{f}$ supporting cell. Similar findings reported by $[10,15,20,28]$. Mitochondria could not be observed indicating slow metabolic activities in supporting cells.

In C. punctata, olfactory epithelium shows goblet cells filled with Golgi complex and rough endoplasmic reticulum. Secretion of goblet cells helps in facilitating the odorant removal $[10,29]$. C. punctata is a bottom dweller fish prefer to live in the mud. Secretion of goblet cell may help in decreasing the friction of water in the chamber as well as protecting the epithelium from coming in contact with the hazardous material to some extent [22]. White cell is reported in the neuroepithelium of rainbow trout [30], and in olfactory epithelium of $H$. fossilis [20]. Similar cell is seen in the olfactory epithelium of $C$. punctata. Basal cells in the fish under study are present towards the basal 
region just above the basal lamina. These cells work as stem cells for regeneration of lost or damaged non-sensory and goblet cells $[24,25]$. These cells regenerate the olfactory epithelium and are characterized by short life span according to $[12,19]$. The ORCs may be replaced throughout the life by these proginator basal cells. This view is supported by presence of rough endoplasmic reticulum in the cytoplasm of these cells.

ONL is formed of axons of ORCs of C. punctata as in $L$. rohita [31], H. fossilis [18], N. notopterus [11]. GL is area where fibers of ONL synapse with dendrites of MCs. Glomeruli of GL are histologically distinct units that serve as the basic modules in the information processing and as a relay station to several higher brain areas [32].

Multipolar, large sized MCs with triangular nucleus form MCL. Axons of mitral cells originate in the basal part of the soma, become myelinated after some distance [33] and project in the medial and lateral olfactory tracts [34]. They terminate on various telencephalic areas [35].

In the olfactory bulb of $C$. punctata on ventro-medial and dorso-medial side, giant cells of the NT have been identified These ganglion cells are also noted in Ictalurus punctatus [36], C. batrachus [37], C. mrigala [26], L. rohita [16]. NT axons travel caudally via medial olfactory tract (MOT) and project to the retina, various brain areas and pineal organ suggesting their role in reproductive behavior, conduction of sex related olfactory stimuli and modulation of visual inputs to the brain $[26,38]$.

\section{Conclusions}

In $C$. punctata, the olfactory organs are placed in the snout and are paired. The olfactory organs include olfactory rosette, olfactory nerve and olfactory bulb. Olfactory rosette has olfactory lamellae are arranged in parallel fashion. The olfactory rosette is oval in shape peculiarly do not show central raphe in olfactory rosette. In TEM study, sensory region of the olfactory epithelium shows cORCs with bipolar neurons. Nucleus of ORCs is elongated. In the cell body, rough endoplasmic reticulum, and mitochondria are aggregated at the apical region. Mucous secreting goblet cells are distributed in the surface area of both sensory and non sensory regions of olfactory epithelium. The olfactory bulb is sessile. Olfactory nerve is long and caudally connected to olfactory bulb. Olfactory bulb concentrically possesses four layers, ONL, GL, MCL and GCL.

\section{Acknowledgements}

Authors feel grateful to the Department of Zoology Rashtrasant Tukadoji Maharaj Nagpur University Campus, Nagpurand All India Institute of Medical Science, New Delhi for providing facilities of transmission electron microscopy to persue this work.

\section{REFERENCES}

[1] Buck L., Axel, R.. "A novel multigene family may encode odorant receptors: a molecular basis for odor recognition". Cell, Vol. 65,175-187, 1991.

[2] Zeiske E. "Morphologische Untersuchungen am Geruchsorgan von Zahnkarpfen" (Pisces, Cyprinodontoidea ). Journal of Morphology, Vol. 74, 1-16, 1973.

[3] Singh, H.R. "On the structure and relation of the habenula in some teleost”. Zool. Beitrage. Vol.15, 457-464, 1969.

[4] Mandal D.K., Roy D., Ghosh L. "Structural organization of the olfactory epithelium of a spotted snakehead fish, Channa punctatus". Acta Ichthyologica et Piscatoria, Vol.35, No.1, 45-50, 2005.

[5] Bhute Y.V., Baile V.V. "Organization of the olfactory system or the Indian Major Carp Labeo rohita (Ham): A scanning and Transmission Electron Microscopy study". Journal of Evolutionary Biochemistry and Physiology, Vol.43, No.3, 342-349, 2007.

[6] Chakrabarti P. "Histological and histochemical studies on the olfactory rosette of Mugil parsia (Hamilton)". Folia Morphologica, Vol.64, No.1, 41-46, 2005

[7] Chakrabarti P., Ghosh, S.K.. "Histoarchitecture and scanning electron microscopical study of the olfactory epithelium in the exotic fish, Puntius javanicus (Bleeker)". Archieves of Polish Fisheries, Vol.18, 173-177, 2010.

[8] Kluver H., Barrera E.. "A method for the combined staining of cells and fibers in the nervous system". Journal of Neuropathology and Experimental Neurology, Vol.12, 400-403, 1953.

[9] Hara T.J. "Olfaction in fish". Progress in Neurobiology, Vol.5, 271-335, 1975.

[10] Masram S.C., Baile V.V. "Ultrastructure of the olfactory organ in the striped Snakehead Ophiocephalus striatus (Bloch)". International Journal of Pharmacy and Biological Sciences, Vol.5, No.3, 955-964, 2014.

[11] Patle P.J., Baile V.V. "Morphology, morphometry and neuroanatomy of the olfactory Epithelium and the olfactory bulb of a feather back fish, Notopterus notopterus". International Journal of Life Sciences, Vol.2, No.1, 1-12, 2014.

[12] Zeiske E., Theisen B., Breucker H. "Structure, development and evolutionary aspects of the peripheral olfactory system" in Fish chemoreception Hara, T. J. (ed.). London: Chapman and Hall, 1992, pp. 13-39.

[13] Kumari K. "Morphology and of the olfactory rosette of a teleostean fish: Catla catla (Ham.)". Our Nature, Vol.6, 3037,2008

[14] Ghosh S. K., Chakrabarti P. "Structural characterization of the olfactory epithelium of fresh water olive barb, Puntius sarana (Hamilton, 1822)". International Journal of Aquatic Biology, Vol.2, No.3, 147-154, 2014.

[15] Mokhtar D., Elhafecz, H.H. "Light and electrom-microscop 
ic studies of olfactory organ of red-tail shark, Epalzeorhynchos bicolor (Teleostei: Cyprinidae)". Journal of Microscopy and Ultrastructure, Vol.35, 1-14, 2014.

[16] Bhute Y.V., Masram S.C., Raut, I.N., Baile V.V. "Cytoarchitectonic pattern of the olfactory system, forebrain and pituitary gland of the Indian Major Carp, Labeo rohita". Annal of Neuroscience, Vol.14, 30-35, 2007.

[17] Baby S. M., Ueck M., Prasad Rao P. D.. Gonadotropin releasing hormone immuno reactive neurons and associates nicotinamide adenine nucleotide phosphate diaphorase positive neurons in the brain of teleosts, Rhodeus amarus. General and Comparative Endocrinology, Vol.120, 44-54, 2000 .

[18] Masram S.C. "Role of neuropeptides and Neurohormones in the regulation of piluitary gland activity in some food fishes". Thesis for Ph.D work R.T.M. Nagpur University, 2010

[19] Yamamoto M. "Comparative morphology of the peripheral olfactory organ in teleosts". In Hara, T.J. (ed.) Chemoreception in fishes. Amsterdam: Elsevier, 1982, pp. $39-59$.

[20] Datta N.C., Das M.K., Bandyopadhyay B.K. "Functional anatomy of the olfactory apparatus of Puffer fish, Sphaeroides oblongus (Bloch)". Zool. Polon. Vol.30: 141-148, 1983.

[21] Waryani B., Zhao Y., Zhang C., Dai R., Abbasi A.R. "Anatomical Studies of the olfactory epithelium of two caves fishes sinocyslosheilus jii and $S$. fuscodorsalis (Cyprini forms: cyprinidae) from China". Pakistan Journal of Zoology, Vol.45, No.4, 1091-1101, 2013.

[22] Datta N.C., Bandopadhyay S. "Ultrastructure of cell types of the olfactory epithelium in a catfish, Heteropneustes fossilis (Bloch)". Journal of Bioscience, Vol.22, No.2, 233-245, 1997.

[23] Zielinski B., Hara T.J. "Morphological and physiological development of olfactory receptor cell in rainbow trout (Salmo gairdneri) embryos". J. comp. Neurol.,271, 1988.

[24] Suzuki Y., Tekafida M. "Keratins in the developing olfactory epithelia”. Developmental Brain Research, Vol.59, 171-178, 1991.

[25] Frabman A. L. "Developmental biology of olfactory sensory neurons". Seminars in Cell Biology, Vol.5, No.3, 3-10, 1994.

[26] Biju K.C., Singru P.S. Schreibman M.P., Subhedar, N.K. "Reproductive phase related expression of GnRG-like immunoreactivity in the olfactory receptor neurons, their projections to the olfactory bulb and in the nervous terminalis in the female Indian major carp Cirrhinus mrigala (Ham.)". General and comparative Endocrinology, Vol.133, 358-367, 2003.

[27] Chakrabarti P., Ghosh S.K.. "Histological and ultrastructural studies of the olfactory epithelium of spotted butter fish scatophagus". Archives of Polish Fisheries, Vol.70, No.2, 74-79, 2011.

[28] Thornhill R.A.. "The Ultrastructure of the olfactory epithelum of the lamprey Lampetra Fluviatilis. Journal of Cell Science, Vol.2, 391-004, 1967.

[29] Horning D.E., Mozell M.M., "Accessibility of odorant molecules to the receptors" in Biochemistry of taste and olfaction in Cagan" R.H. and Kare, M.R. (eds.). New York: Academic Press, 1981, pp. 33-45.

[30] Evans R.E., Zielinski B., Hara T.J., "Development and regeneration of the olfactory organ in rainbow trout" in Chemoreception in fishes, Hara, T.J. (ed.). Amsterdam: Elsevier, 1982, pp15-37.

[31] Baile V. V., Raut I. N., Bhute Y. V. "Organization of olfactory system, forebrain and pituitary gland of a teleost, Notopterus notopterus". Annals of Neuroscience. Vol.15, 43-50, 2008.

[32] Shepherd G. M. "Discrimination of molecular signals by the olfactory by the olfactory receptor neuron". Neuron, Vol.13, 771-190, 1994.

[33] Kosaka T., Hama K. "Synaptic Organization in the teleost olfactory bulb of the gold fish (Carassius auratus)". Journal of Comparative Neurology, 212 Vol., 365- 384, 1982.

[34] Fujita I., Satou M., Ueda, K. "Morphology of physiologically identified mitral cells in the carp olfactory bulb: a light microscopic study after intracellular staining HRP”. J. Comp. Neurol. Vol.267, 253-268, 1988.

[35] Satou M. "Synaptic organization, local neuronal circuitry, and Functional segregation of the teleost olfactory bulb". Progress in Neurobiology, Vol.34, 115-142, 1990.

[36] Bass A.H. "Olfactory bulb efferents in the channel catfish, Ictalurus punctatus". Journal of Morphology, Vol.169, 91-111, 1981.

[37] Khan F.A., Saha S.G., Sarkar S., Subhedar, N. " $\beta$-endorphin-like immunoreactivity in the forebrain and pituitary of teleosts Clarias batrachus (Linn.)" Gen. Comp. Endorcrinol. Vol.113, 290-301, 1999.

[38] Singru P.S., Sakharkar A.J., Subhedar, N.K. "Neuronal nitric oxide synthase in the olfactory system of an adult teleost fish" Oreochromis mossambicus. Brain Research, Vol.977, 157-168, 2003. 